\title{
Treatment Outcome of Scalp Angiosarcoma: A Single Institute Experience
}

\author{
Sung Seok Ryu' ${ }^{1}$ D, Seung Jin Park ${ }^{2}$ D , Young Ho Jung ${ }^{1}$, Seung-Ho Choi ${ }^{1}$, \\ Soon Yuhl Nam ${ }^{1}$, Sang Yoon Kim ${ }^{1}$, and Yoon Se Lee ${ }^{1}{ }^{10}$ \\ ${ }^{I}$ Department of Otolaryngology-Head and Neck Surgery, Asan Medical Center, University of Ulsan College of Medicine, Seoul; and \\ ${ }^{2}$ Department of Otorhinolaryngology, University of Ulsan College of Medicine, Gangneung Asan Hospital, Gangneung, Korea
}

\section{두피 혈관육종(Scalp Angiosarcoma)의 치료 성적: 단일 기관의 경험}

류성석 ${ }^{1} \cdot$ 박승진 $^{2} \cdot$ 정영호 $^{1} \cdot$ 최승호 $^{1} \cdot$ 남순열 $^{1} \cdot$ 김상윤 $^{1} \cdot$ 이윤세 $^{1}$

울산대학교 의과대학 서울아산병원 이비인후과학교실, ${ }^{1}$ 울산대학교 의과대학 강릉아산병원 이비인후과학교실 ${ }^{2}$

Received October 26,2020

Revised November 20, 2020

Accepted November 20, 2020

Address for correspondence

Yoon Se Lee, MD, PhD

Department of Otolaryngology-

Head and Neck Surgery,

Asan Medical Center,

University of Ulsan

College of Medicine,

88 Olympic-ro 43gil, Songpa-gu,

Seoul 05505 , Korea

Tel $+82-2-3010-3710$

Fax $+82-2-489-2773$

E-mail manseilee@gmail.com
Background and Objectives Scalp angiosarcoma is a rare but aggressive vascular malignancy. It is often found in the advanced state and tends to cause distant metastasis at an early stage. There is no consensus on a treatment modality, although wide excision followed by adjuvant therapy is currently used. The purpose of this study was to analyze the treatment results and disease progress pattern of scalp angiosarcoma in a single institution.

Subjects and Method We enrolled patients who diagnosed with scalp angiosarcoma at Asan Medical Center from March 2011 to September 2019. Disease course and prognostic factors were analyzed by estimating overall survival rate and disease free survival.

Results A total 12 patients were enrolled in this study. The median overall survival was 16.0 months. The 3-year-survival rate was $10.6 \%$, and the median disease free survival was 5.0 months. On the average, it took 11.4 months till death after recurrence.

Conclusion Although wide surgical excision and multiple adjuvant therapies are employed, scalp angiosarcoma showed frequent recurrences and metastasis which led to poor outcomes. Further investigations for scalp angiosarcoma are necessary to improve treatment outcomes. Korean J Otorhinolaryngol-Head Neck Surg 2021;64(9):652-8

Keywords Head and neck cancer; Hemangiosarcoma; Radiation therapy; Scalp; Surgery; Survival rate.

\section{서 론}

두피 혈관육종(scalp angiosarcoma)는 혈관 내피세포에서 유래하는 악성 종양으로, 발병이 드물고 혈관육종 중 $27 \%$ 를 차지한다. ${ }^{1)}$ 또한 빠른 진행을 보이고 광범위 병변 절제술 및 술후 보조요법에도 불구하고 매우 불량한 예후를 보이는 것 으로 보고되고 있다. ${ }^{2,3)}$ 비교적 고령, 남성에서 호발한다. ${ }^{4}$ 두

This is an Open Access article distributed under the terms of the Creative Commons Attribution Non-Commercial License (https://creativecommons.org/licenses/by-nc/4.0) which permits unrestricted non-commercial use, distribution, and reproduction in any medium, provided the original work is properly cited.
피 혈관육종의 발생기전은 명확하게 알려져 있지 않으나 만성 적인 부종이나 과거의 방사선 조사력 등이 원인이라는 보고 가 있다. ${ }^{5,6}$

현재 두피 혈관육종의 치료법으로 정립되어 있는 방법은 없 지만 병변의 광범위 절제술 후 보조적 방사선 요법을 주로 사 용하고 있다. ${ }^{7)}$ 항암치료는 다른 육종에서 사용하는 anthracycline, ifosfamide, taxane 계열의 약제를 주로 사용하고 있 으며 보조적인 방법으로 사용한다. 수술적 제거와 방사선치 료, 항암치료를 같이 사용할 경우 좀 더 개선된 치료 결과를 보인다는 보고가 있지만 대규모 연구가 아니기 때문에 적극적 
Treatment Outcome of Scalp Angiosarcoma I Ryu SS, et al.

으로 적용하기는 어렵다. ${ }^{8)}$ 여러 치료 방법에도 불구하고 5년 생존률이 10 54\% 정도로 보고되고 있다. ${ }^{910)}$ 수술적 제거 후 국소부위의 재발과 함께 초기에 발견되어도 전이를 잘한다는 점이 치료 실패의 주된 원인이다.

본 연구에서는 단일기관에서의 치료를 받은 두피 혈관육종 환자들의 영상의학적, 병리학적 소견을 파악하고 이들의 치료 성적 및 진행 경과를 문헌 고찰과 함께 소개하고자 하였다.

\section{대상 및 방법}

본 연구에서는 2011년 3월 2019년 9월까지 울산의대 서울 아산병원 이비인후과에서 두피 혈관육종으로 진단받고 치료 받은 환자를 대상으로 하였다. 처음 치료로 수술을 받았고 관찰 기간이 6 개월 이상인 환자의 의무기록을 후향적으로 분 석하였다. 타원에서 초치료를 받은 경우, 진단 당시 원격전이 가 발견된 경우, 완화를 목적으로 수술을 진행한 경우, 이전 방사선치료 또는 항암화학요법을 시행 받은 환자는 제외하였 다. 이번 연구는 서울아산병원 임상연구심의위원회(Institutional Review Board)의 승인을 받고 동의서를 면제받은 뒤 진행하였다(2020-1523).

수술 시 $2 \mathrm{~cm}$ 이상의 변연부절제연을 두기 위해 노력하였 으며 수술 전 영상의학적 검사 또는 세침흡인 검사에서 전이 의 소견이 의심되거나 보일 경우 이하선절제술 혹은 경부청 소술을 시행하였다. 수술 후 병리 소견에서 $5 \mathrm{~mm}$ 미만의 절 제연과의 거리 혹은 절제연 침범이 있을 경우 방사선 치료를 보조적으로 사용하였다. 총 12 명의 환자가 상기 기준에 해당 되었으며 환자의 나이, 성별, 영상의학적 소견, 병변의 조직학 적 소견, 수술 범위, 술후 재건 여부, 술후 보조요법, 종양 및 림프절의 병리학적 소견을 조사하여 치료 성적에 영향을 미 치는 인자들을 조사하였다. 치료 성적의 지표로는 무병생존 율(disease free survival rate, DFS)과 전체 생존율(overall survival rate, OS)이 사용되었다.

통계학적 분석에는 SPSS(22.0; IBM Corp., Armonk, NY, USA)를 사용하였으며 DFS와 OS를 분석하기 위해 KaplanMeier method를 사용하였다. 양측 검정을 이용하여 $p-v a l-$ $\mathrm{ue}$ 가 0.05 미만일 경우를 통계학적으로 유의미하다고 판정하 였다.

\section{결 과}

총 12 명의 환자 군이 모집되었다. 환자 군의 평균 연령은 78.3세(64 92) 였으며 성별로는 남성이 11명(91.7\%), 여성이 1 명(8.3\%)이었다. 평균 추적 관찰 기간은 16.8 개월(4.0 41.0)
Table 1. Characteristics of patients and tumor $(n=12)$

\begin{tabular}{lc}
\hline \multicolumn{1}{c}{ Variables } & Results \\
\hline Age (years) & $78.3(64-92)$ \\
Sex & 11 \\
Male & 1 \\
Female & \\
Chief complaint & 10 \\
Scalp mass (hemorrhagic, dark, purple) & 2 \\
Scalp ulcerative lesion & $16.8(4.0-41.0)$ \\
Follow-up period (months) & $7.7(3.50-16.00)$ \\
Tumor size (centimeters) & \\
Node metastasis & 3 \\
Positive* & 9 \\
Negative & \\
Resection margin & 3 \\
Positive & 9 \\
Negative & $16.0(4-41)$ \\
Median overall survival rate (months) & \\
Recurrence event & 9 \\
Recurrence site & 8 \\
Primary & 2 \\
Neck & \\
Distant & \\
No recurrence & \\
\hline &
\end{tabular}

*all neck lymph node metastasis was ipsilateral side

이었다(Table 1).

일반적인 두피 혈관육종의 영상의학적 소견으로 $\mathrm{MR} \mathrm{im}^{-}$ age상 $\mathrm{T} 1$ 영상에서 동등 신호강도를 보이며 출혈이 동반된 경우 T2 image에서 고신호강도를 동반할 수 있으며, 가장 특 징적인 소견으로는 $\mathrm{T} 1, \mathrm{~T} 2$ 영상 모두에서 저신호강도를 보이 는 고유량 혈관(high-flow vessels)이 종양 내에 존재하는 것 이다. ${ }^{11)}$ 하지만 이러한 영상 소견들 역시 비교적 비특이적인 소견으로 확인 후 조직학적 진단이 필요하다.

본 연구에서 12 명의 환자 중 1 명의 자기공명영상(MRI)에서 두피에서 유래하는 결절성 병변이 T1 강조, T2 강조영상에서 동등 신호강도를 보이며, $\mathrm{T} 1$ 조영증강영상에서 고신호강도를 보였다. 해당 영상에서 고유량 혈관은 확인되지 않았다. 현성 확산계수영상(apparent diffusion coefficient map)에서 diffusion restriction을 보이지 않았으며 병변의 두개골 침범 소 견은 드물었다(Fig. 1).

수술 검체의 육안적 소견으로 다수의 출혈성 괴사를 보이 는 조직을 관찰할 수 있었다(Fig. 2A). 현미경적 소견으로 혈 관 내피세포의 핵의 크기 및 세포질의 양이 증가되어 있고 신 생혈관 구조물들이 관찰되었다. 해당 구조물들은 $\mathrm{ERG}, \mathrm{CD} 31$ 염색에서 양성 소견을 보여 혈관 내피세포에서 유래하였음을 확인할 수 있었다(Fig. 2B-D). 

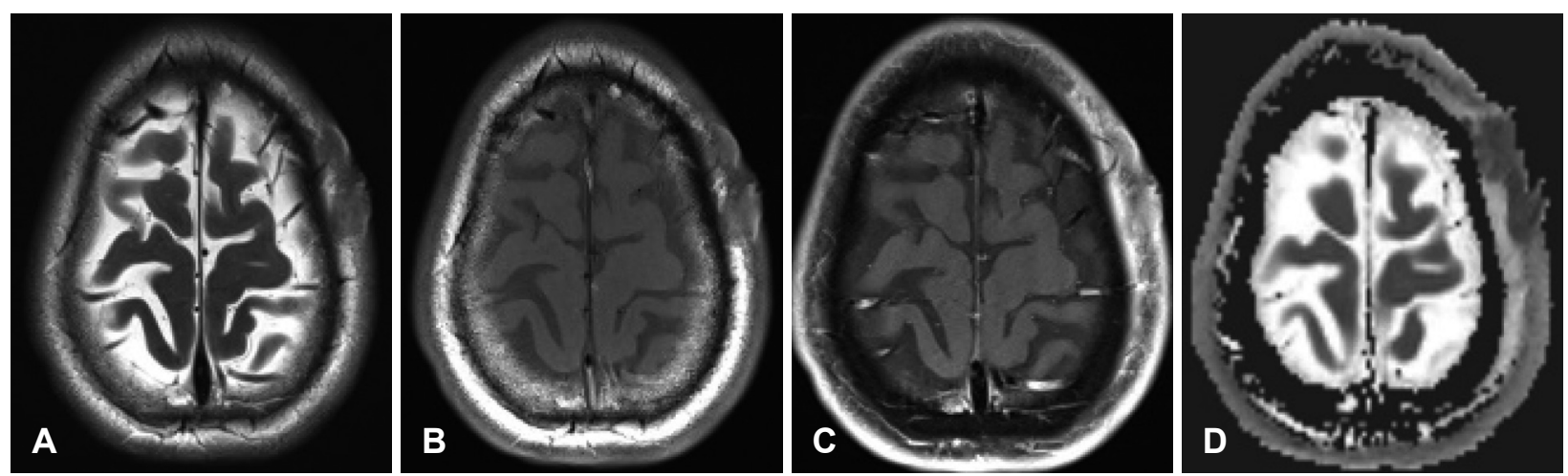

Fig. 1. Radiological findings. The nodular lesions arising from left frontal scalp show intermediate signal intensity at T2-weighted image (A). Intermediate signal intensity at T1-weighted image (B). Enhancement at T1 enhance image and no evidence of bony calvarium invasion (C). The lesions show diffusion restriction at apparent diffusion coefficient map (D).

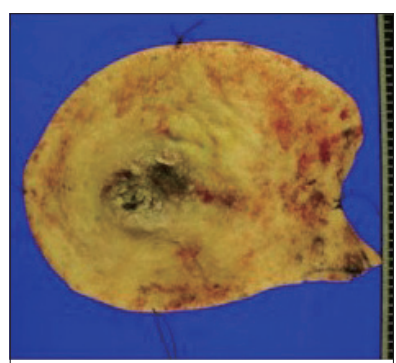

A Gross image

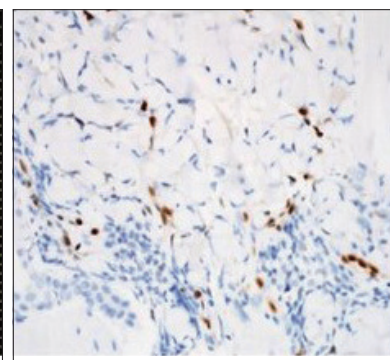

B
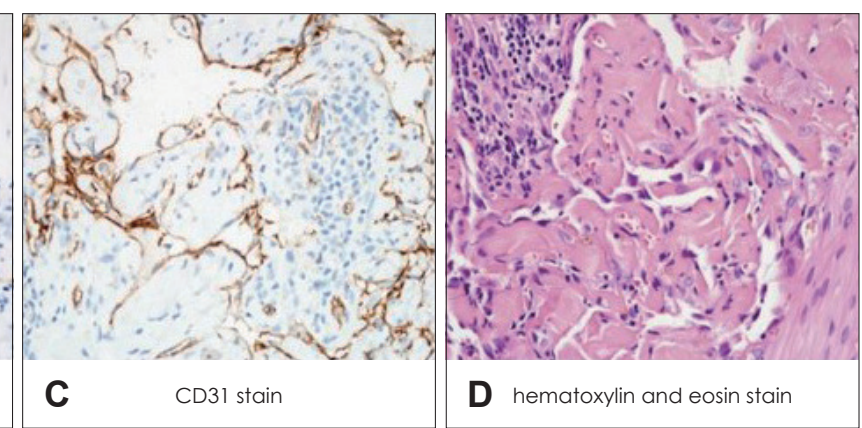

Fig. 2. Gross \& microscopic features of angiosarcoma ( $\times 400$ for microscopic findings). Multiple hemorrhagic features with necrotic portion in gross image (A). Positive ERG and CD31 staining implies that this tumor originated from endothelial cell marker (B, C). Neoplastic vascular structures; increased vascular endothelial cell's nucleus size, cytoplasm (D). ERG: erythroblast transformation-specific [ETS]related gene.

광범위 병변 절제술을 시행받은 12예의 수술 중 8예에서 동측 이하선 절제술 및 경부청소술을 함께 시행하였다. 경부 청소술 8예 중 2예에서는 치료적 경부청소술이었다. 예방적 경부청소술 6예는 level I-II(1예), level I-III(3예), level II-III (1예), Ievel II(1예)에서 시행하였다. 두피 혈관육아종에 대한 예방적 경부청소술의 효용성과 범위에 대한 공통된 의견이 없어서 이하선암, 안검 및 측두부 피부암의 예방적 경부청소 술의 범위를 고려하여 수술범위를 결정하였다. 병변만 광범위 하게 제거한 경우는 4예가 있었다.

수술 부위에 대한 재건은 2명에서 국소 피판(pectoralis major musculocutaneous flap, rotational local flap)이 사용되 었다. 전외측대퇴 유리피판(anterolateral thigh free flap)과 피부 이식술(split thickness skin graft)을 각각 5 명의 환자에 게 사용하였다.

수술 절제연 침범은 3 명에서 확인되었다. 종양의 평균 크기 는 $7.7 \mathrm{~cm}(3.5 \sim 16.0)$, 평균 침범의 깊이는 $0.94 \mathrm{~cm}$ 였다. 경부 림프절 전이는 3 명의 환자에게서 확인되었고 모두 동측 림프 절 전이로 확인되었다. 술후 보조요법으로 방사선치료 7명 (58.3\%), 항암화학요법 2명(16.7\%), 동시항암방사선요법 1명
(8.3\%)의 환자에게서 시행되었다. 2 명(16.7\%)의 환자에게서 술 후 보조요법을 시행하지 않았다.

수술 후 6 개월 이내에 병변이 국소에서 진행한 환자는 3명 (25\%)이었으며 잔존 병소로 고려하였다. 재발은 9 명(75\%)의 환자에게서 발생하였으며 수술 후 재발까지 평균 8.5 개월이 소요되었다. 재발한 9 명의 환자 모두 3년 이내에 재발을 하였 다. 국소 재발은 8예(88.9\%)가 있었다. 수술 절제연 침범이 없 었던 9명의 환자 중 국소 재발이 7예(77.8\%) 있었다. 국소 재 발 환자의 치료로 수술 및 술후 방사선치료 2예, 수술 및 술 후 항암화학요법 1예, 방사선치료 1예, 항암화학요법 2예, 동 시항암방사선요법 1예, 동시항암방사선요법 후 수술적 치료가 1 예에서 시행되었다. 재발 당시 원격전이는 2명(22.2\%)에서 있 었으며 모두 폐, 간에서 발생하였다. 상기 2명 중 1명에서 국 소 재발도 함께 확인되었다. 재발이 확인된 후 사망까지 평균 11.4 개월(4 19)이 소요되었다.

전체 생존 기간의 중앙값은 16.0 개월(4 41)이었다. 1년, 3년 전체 생존률은 각각 $83.3 \%, 10.6 \%$ 였다. 재발하지 않은 환자 3 명 중 2 명의 경우 잔존 질환의 진행으로 4 개월, 6 개월 뒤 사 망하였다. 나머지 1 명의 환자는 재발 소견 없이 13 개월간 추 

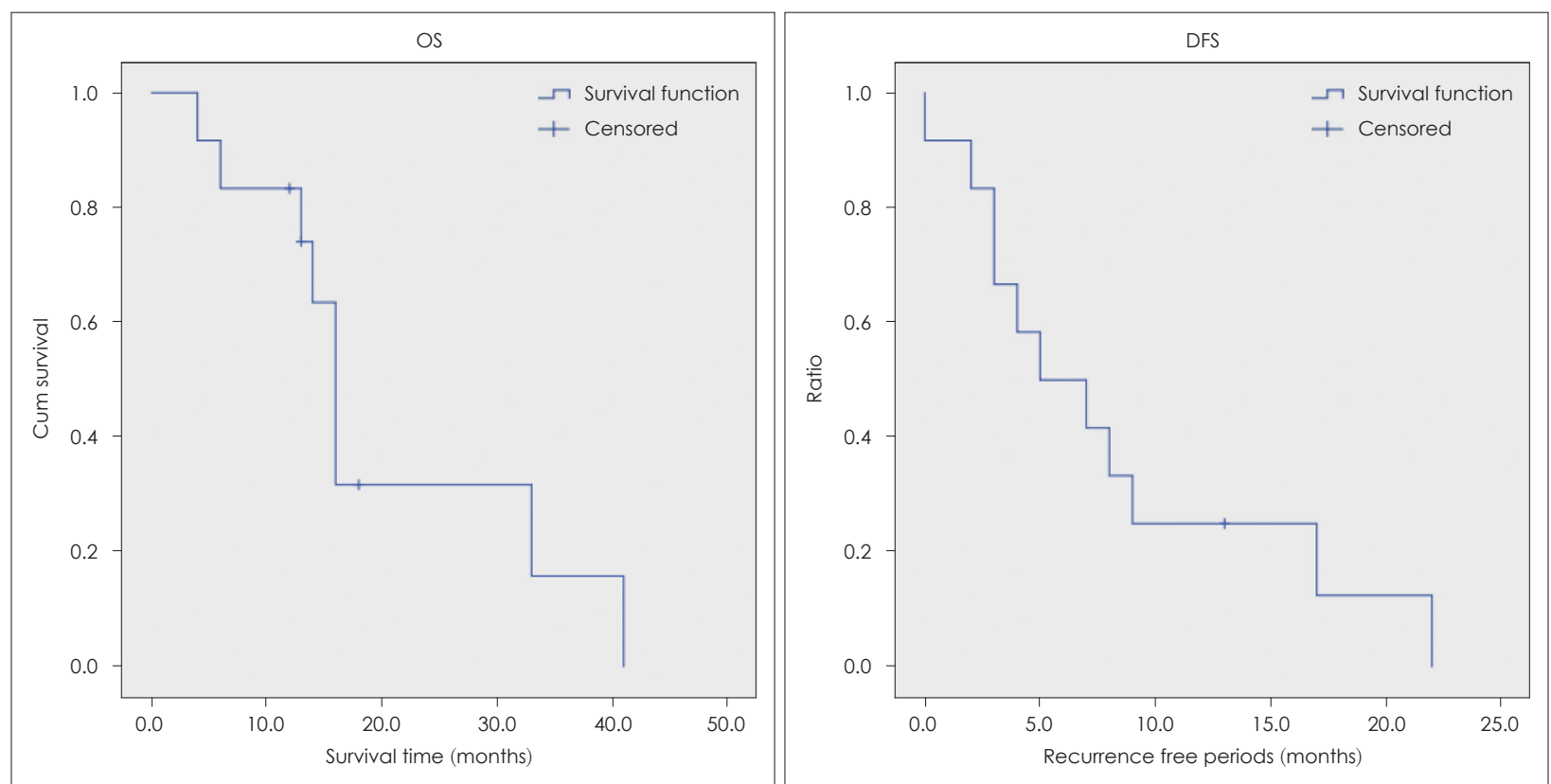

Fig. 3. OS \& DFS. Median overall survival was 16.0 months. 3-year-survival rate was $10.6 \%$. Median DFS was 5.0 months. 1-year-DFS was $25 \%$. On average, it takes 11.4 months of death after recurrence. OR: overall survival rate, DFS: disease free survival rate.

적 관찰 중이다. 무병생존기간의 중앙값은 5.0개월(0 22)이었 으며 1년, 3년 무병생존률은 각각 25\%, 0\%였다(Fig. 3).

\section{고 찰}

혈관육종(angiosarcoma)은 혈관 및 림프관에서 유래하는 악성 종양으로, 두경부에서 발생하는 육종의 $15 \%$ 정도를 차 지하며, 전체 연조직 육종의 약 $1 \%$ 를 차지한다. ${ }^{12,13)}$ 전체 혈관 육종 중 $27.0 \%$ 에서 두경부에서 발생한다. ${ }^{10)}$ 예후가 나쁜 것 으로 알려져 있으며, 이번 연구에서 확인된 환자의 경우에도 광범위 절제를 시행했음에도 불구하고 대부분의 환자들이 재발을 하였고 이로 인해 사망하였다. 국소재발로 시작해서 원격전이가 발생한 경우가 대부분이었으며 1 명에서 재발 당시 국소 재발 없이 폐와 간에 원격 재발 소견을 보였다. 잔존 병 소의 진행으로 폐 전이가 발생한 경우가 1 명에서 관찰되었다.

피부 혈관육종의 경우 푸른색 또는 보라색의 피부 병변이 수 개월에 걸쳐 발생 및 병변의 크기가 증가하는 임상경과를 보인다. ${ }^{14,15)}$ 해당 병변은 경계가 명확하지 않고 단일 병변보다 는 동시에 다수의 병변이 흔하게 관찰된다. ${ }^{16)}$ 이번 연구에서도 두피의 출혈성, 검은색 또는 보라색을 띄는 종물을 주소로 하는 환자가 $83.3 \%$ 를 차지했다. $16.7 \%$ 의 환자에게서 두피의 궤양성 병변으로 발생하였다. 이를 바탕으로 병변의 발생이 드물지만 나이가 많은 환자가 두피에 출혈성 종물 또는 궤양 성 피부 병변을 보이는 경우 혈관육종을 감별해야 할 것이다.

일반적인 혈관육종의 치료는 충분한 절제연을 포함한 병
변의 광범위 절제 및 술후 방사선치료를 시행하는 것으로 알 려져 있다. ${ }^{10)}$ 두경부 혈관육종도 이와 같이 수술 절제연의 침 범이 없는 병변의 광범위 절제술이 선호되며, 수술 전후 보 조 요법의 동반이 시행되고 있다..$^{17)}$ 여러가지 치료법의 시도에 도 두경부 영역의 피부 혈관육종의 5년 생존률은 10 54\%로 보고되고 있다. ${ }^{18,19)}$

수술적 치료가 불가능한 진행된 국소 혈관육종 및 전이된 혈관육종에서 anthracycline, ifosfamide, taxane 계열의 항 암치료를 시행한 임상 연구들이 이루어 졌으며, 해당 연구들 에서 혈관육종의 치료 반응률(overall response rate)은 17 $89 \%$, 무진행 생존 기간의 중앙값(median progression-free survival)은 4.0 9.5개월로 보고되었다. ${ }^{20,21)}$

최근 사용하고 있는 표적 항암치료제로 Bevacizumab(vascular endothelial growth factor-A monoclonal antibody), Sorafenib [multi-targeted tyrosine kinase inhibitor(TKI)], Sunitinib (multi-targeted TKI) 등이 있다. ${ }^{20,22-24)}$ 하지만 두피 혈관육 종에만 국한해서 대규모 임상연구를 진행하기 쉽지 않아 전 신에 발생하는 육종 및 혈관육종을 포함한 연구를 진행하였 다. 이러한 연구에서 혈관육종의 치료 반응율은 $0 ~ 14 \%$, 무 진행 생존 기간의 중앙값은 4.7개월, 전체 생존 기간의 중앙 값은 13.5 14.2개월로 보고되고 있어 결국은 생존율에서 이 득은 많지 않은 것으로 알려져 있다. ${ }^{20,22-24)}$

본 기관에서는 광범위 절제 후 항암치료 여부와 상관없이 방사선 치료를 선택적으로 사용한 경우가 많았다(66.7\%). 발 견 당시 원격전이가 있는 경우는 연구에서 제외하였고, 수술 


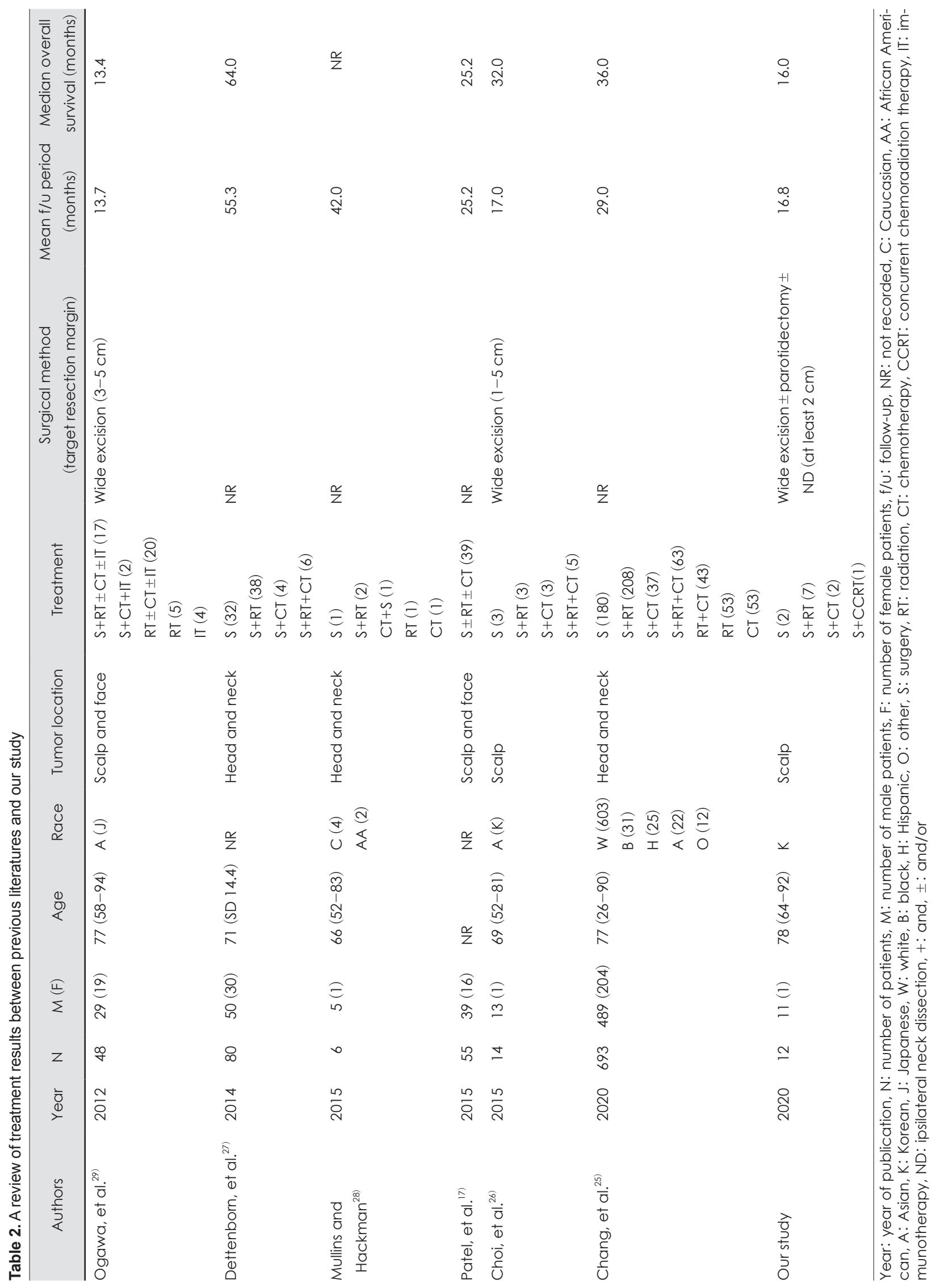


과 방사선 치료 후 재발한 환자 중 항암제 또는 표적 치료제 를 사용한 경우가 7예(58.3\%) 있었으나 참여한 환자의 수가 많지 않아 치료의 반응율을 평가하는 데 제한이 있었다. 본원 에서의 두피 혈관육종 환자의 치료 결과, 광범위한 수술적 절 제 및 술후 보조요법에도 불구하고 전체 생존 기간의 중앙값 16.0 개월, 3 년 전체 생존률이 $10.6 \%$ 로 불량한 예후를 보였으 며, 이는 문헌에서 발표된 전체 생존 기간의 중앙값 25.2 28.4 개월, 5년 전체생존률 21.7 38.0\%에 비해 낮았다. ${ }^{16-18)} 75 \%$ 의 환자에서 수술 후 평균 11.4 개월에 재발이 발생하였으며 9명 의 환자에서 수술 절제연 침범이 없음에도 불구하고 $77.8 \%$ 의 국소 재발이 발생하였다. 전체 재발 환자 중 $22.2 \%$ 에서 폐, 간 에서의 원격 재발이었다.

본원에서의 환자 및 치료 성적을 기존 문헌들과 비교해 보 면 본원에서의 환자의 평균 연령이 기존 문헌들보다 많았고, 병변의 위치 또한 두피(scalp)에 발생한 혈관육종만을 조사 하였다. 기존 문헌들을 비교해 보면 전체적인 두경부의 혈관 육종에 비하여 두피와 얼굴에 발생한 혈관육종의 예후가 비 교적 나쁜 것을 확인할 수 있다. 본 연구에서도 마찬가지로 두 피 혈관육종은 매우 불량한 예후를 보이는 것을 확인할 수 있었다(Table 2). ${ }^{17,25-29)}$

따라서 이러한 두피 혈관육종의 불량한 예후의 대하여 치 료 전 환자 및 보호자와 충분한 상의를 하고 치료 시작을 결 정하는 것이 필요할 것이다.

이번 연구에서 통계적 유의성을 얻을 정도의 충분한 환자 수를 이용한 연구를 진행하지 못하였다. 하지만 기존 문헌에 발표된 연구와 같이 잦은 재발 및 전이를 보이며 매우 나쁜 예후를 확인할 수 있었다.

향후 좀 더 많은 환자 군 및 긴 추적 관찰 기간을 통해 추 가적인 분석이 필요할 수 있겠다. 또한 두피 혈관육종의 치료 성적 향상을 위하여 술전 보조요법, 술후 molecular target agent, immunotherapy 등의 다양한 치료 방법들의 연구가 필요할 것이다.

결론적으로, 두피 혈관육종은 광범위 절제와 술후 방사선 치료에도 불구하고 국소 재발과 원격전이를 자주 일으키며 나쁜 예후를 보이는 것으로 알려져 있다. 기존의 연구들의 결 과와 마찬가지로 본 연구에서도 광범위 절제, 술후 다양한 보조요법에도 불구하고 빠른 재발 및 낮은 생존률을 보였다. 낮은 치료 성적을 해결하기 위해 치료 표적을 찾고 다양한 임 상 시험을 통해 최선의 치료방법을 찾는 것이 필요하겠다.

\section{Acknowledgments}

This research was funded by the National Research Foundation of Korea, grant numbers MSIP; 2016R1C1B1014827 and 2019R1 H1A1080141 to Y.S.L.

\section{Author Contribution}

Conceptualization: Seung Jin Park, Sang Yoon Kim, Yoon Se Lee. Data curation: Seung-Ho Choi. Formal analysis: Soon Yuhl Nam. Investigation: Seung Jin Park. Writing_original draft: Sung Seok Ryu, Young Ho Jung. Writing — review \& editing: Yoon Se Lee.

\section{ORCIDs}

Yoon Se Lee Sung Seok Ryu https://orcid.org/0000-0001-6534-5753

Seung Jin Park https://orcid.org/0000-0001-5861-7386 https://orcid.org/0000-0002-2057-1594

\section{REFERENCES}

1) Fury MG, Antonescu CR, Van Zee KJ, Brennan MF, Maki RG. A 14-year retrospective review of angiosarcoma: Clinical characteristics, prognostic factors, and treatment outcomes with surgery and chemotherapy. Cancer J 2005;11(3):241-7.

2) Gudewer E, Hölzle E, Li L. Widespread cutaneous angiosarcoma of the scalp: Diagnosis and soft tissue reconstruction with a combined double-muscle-free flap and split-thickness-skin graft. Oral Maxillofac Surg 2009;13(2):95-8.

3) Sasaki R, Soejima T, Kishi K, Imajo Y, Hirota S, Kamikonya N, et al. Angiosarcoma treated with radiotherapy: Impact of tumor type and size on outcome. Int J Radiat Oncol Biol Phys 2002;52(4):103240.

4) Holden CA, Spittle MF, Jones EW. Angiosarcoma of the face and scalp, prognosis and treatment. Cancer 1987;59(5):1046-57.

5) Chen KT, Hoffman KD, Hendricks EJ. Angiosarcoma following therapeutic irradiation. Cancer 1979;44(6):2044-8.

6) Sordillo PP, Chapman R, Hajdu SI, Magill GB, Golbey RB. Lymphangiosarcoma. Cancer 1981;48(7):1674-9.

7) Lahat G, Dhuka AR, Lahat S, Smith KD, Pollock RE, Hunt KK, et al. Outcome of locally recurrent and metastatic angiosarcoma. Ann Surg Oncol 2009;16(9):2502-9.

8) Naka N, Ohsawa M, Tomita Y, Kanno H, Uchida A, Myoui A, et al. Prognostic factors in angiosarcoma: A multivariate analysis of 55 cases. J Surg Oncol 1996;61(3):170-6.

9) Mendenhall WM, Mendenhall CM, Werning JW, Reith JD, Mendenhall NP. Cutaneous angiosarcoma. Am J Clin Oncol 2006; 29(5):524-8.

10) Young RJ, Brown NJ, Reed MW, Hughes D, Woll PJ. Angiosarcoma. Lancet Oncol 2010;11(10):983-91.

11) Gaballah AH, Jensen CT, Palmquist S, Pickhardt PJ, Duran A, Broering G, et al. Angiosarcoma: Clinical and imaging features from head to toe. Br J Radiol 2017;90(1075):20170039.

12) Freedman AM, Reiman HM, Woods JE. Soft-tissue sarcomas of the head and neck. Am J Surg 1989;158(4):367-72.

13) Wanebo HJ, Koness RJ, MacFarlane JK, Eilber FR, Byers RM, Elias EG, et al. Head and neck sarcoma: Report of the Head and Neck Sarcoma Registry. Society of Head and Neck Surgeons Committee on Research. Head Neck 1992;14(1):1-7.

14) Mark RJ, Tran LM, Sercarz J, Fu YS, Calcaterra TC, Juillard GF. Angiosarcoma of the head and neck. The UCLA experience 1955 through 1990. Arch Otolaryngol Head Neck Surg 1993;119(9):973-8.

15) Panje WR, Moran WJ, Bostwick DG, Kitt VV. Angiosarcoma of the head and neck: Review of 11 cases. Laryngoscope 1986;96(12): 1381-4.

16) Morrison WH, Byers RM, Garden AS, Evans HL, Ang KK, Peters LJ. Cutaneous angiosarcoma of the head and neck. A therapeutic dilemma. Cancer 1995;76(2):319-27.

17) Patel SH, Hayden RE, Hinni ML, Wong WW, Foote RL, Milani S, et al. Angiosarcoma of the scalp and face: The Mayo Clinic experience. JAMA Otolaryngol Head Neck Surg 2015;141(4):335-40. 
18) Köhler HF, Neves RI, Brechtbühl ER, Mattos Granja NV, Ikeda MK, Kowalski LP. Cutaneous angiosarcoma of the head and neck: Report of 23 cases from a single institution. Otolaryngol Head Neck Surg 2008;139(4):519-24.

19) Pawlik TM, Paulino AF, McGinn CJ, Baker LH, Cohen DS, Morris JS, et al. Cutaneous angiosarcoma of the scalp: A multidisciplinary approach. Cancer 2003;98(8):1716-26.

20) Verschraegen CF, Quinn R, Rabinowitz I, Arias-Pulido H, Muller C. Phase I/II study of docetaxel (D), gemcitabine (G), and bevacizumab (B) in patients (pts) with advanced or recurrent soft tissue sarcoma (STS). J Clin Oncol 2008;26(15 suppl):10534.

21) von Mehren M, Rankin C, Goldblum JR, Demetri GD, Bramwell V, Ryan CW, et al. Phase 2 Southwest Oncology Group-directed intergroup trial (S0505) of sorafenib in advanced soft tissue sarcomas. Cancer 2012;118(3):770-6.

22) Agulnik M, Okuno SH, Von Mehren M, Jovanovic B, Brockstein B, Benjamin RS, et al. An open-label multicenter phase II study of bevacizumab for the treatment of angiosarcoma. J Clin Oncol 2009;27(15 suppl):10522.

23) Maki RG, D'Adamo DR, Keohan ML, Saulle M, Schuetze SM, Undevia SD, et al. Phase II study of sorafenib in patients with metastatic or recurrent sarcomas. J Clin Oncol 2009;27(19):3133-40.
24) Ryan CW, von Mehren M, Rankin CJ, Goldblum JR, Demetri GD, Bramwell VH, et al. Phase II intergroup study of sorafenib (S) in advanced soft tissue sarcomas (STS): SWOG 0505. J Clin Oncol 2008;26(15 suppl):10532.

25) Chang C, Wu SP, Hu K, Li Z, Schreiber D, Oliver J, et al. Patterns of care and survival of cutaneous angiosarcoma of the head and neck. Otolaryngol Head Neck Surg 2020;162(6):881-7.

26) Choi JH, Ahn KC, Chang H, Minn KW, Jin US, Kim BJ. Surgical treatment and prognosis of angiosarcoma of the scalp: A retrospective analysis of 14 patients in a single institution. Biomed Res Int 2015; 2015:321896.

27) Dettenborn T, Wermker K, Schulze HJ, Klein M, Schwipper V, Hallermann C. Prognostic features in angiosarcoma of the head and neck: A retrospective monocenter study. J Craniomaxillofac Surg 2014;42(8):1623-8.

28) Mullins B, Hackman T. Angiosarcoma of the head and neck. Int Arch Otorhinolaryngol 2015;19(3):191-5.

29) Ogawa K, Takahashi K, Asato Y, Yamamoto Y, Taira K, Matori S, et al. Treatment and prognosis of angiosarcoma of the scalp and face: A retrospective analysis of 48 patients. Br J Radiol 2012; 85(1019):e1127-33. 